\title{
Environmental Reporting Practices In Malaysia And Australia
}

Haslinda Yusoff, Universiti Teknologi MARA, Malaysia

Radiah Othman, Massey University, New Zealand

Normahiran Yatim, Universiti Teknologi MARA, Malaysia

\begin{abstract}
The purpose of this paper is to investigate the state of environmental reporting by Malaysian and Australian companies on 'other' reports, i.e. other than annual reports. The paper employs content analysis to study the environmental disclosures made by the selected 100 companies in the two countries. Regression analysis is performed on potential influencing factors for environmental reporting. The findings are also compared to previous studies on environmental reporting in corporate annual reports by Yusoff and Lehman (2008). The paper finds that environmental reporting in 'other' reports (Malaysia and Australia) are largely descriptive and in qualitative form. In addition, the influencing factors for environmental reporting are of similar quality to those made in annual reports, in both countries. These findings imply that this type of communicating environmental information does not contribute greater corporate accountability among companies in fulfilling stakeholders' needs and demands for environmental information. Hence, more efforts are needed to promote better and greener environmental reporting practice. This study comparatively explores the environmental practices and interprets the possible link between influencing factors for environmental reporting and actual environmental reporting practices on a two-country basis, between Malaysia and Australia.
\end{abstract}

Keywords: Environmental Reporting; Publicly Listed Company; Malaysia; Australia

\section{INTRODUCTION}

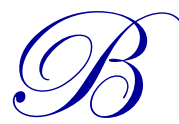

usiness corporations' involvement with environmental activities is a way to enhance values as well as their integrity to create a sustainable base for improved earnings and operations in the future. The increase of global environmental problems alongside the introduction of the Brundtland Report in 1987 has largely influenced businesses to engage in environmental management and practice including environmental reporting. The term 'corporate social accounting and reporting' has been used in numerous ways; Schaltegger and Burritt (2000, p. 272), for instance, describe the term as relating to "data gathered in accounting systems, recognized, classified, measured, calculated or estimated, recorded, verified and then disclosed". Gray et al. (1996) provide a comprehensive definition of corporate social and environmental reporting which indicates that environmental reporting/disclosure practice represents corporate exercise in disseminating environmental information, especially to a wide group of information users.

Preliminary research reveals the lack of investigation of the role environmental accounting and reporting plays in Asian and developing countries (see Gray et al. 1996). Hence, this study intends to explore and investigate companies' practices in reporting environmental information, and a focus on two-country practices is deemed to offer better understanding about the reporting practice. This study extends the work made in Yusoff and Lehman (2008), in which they explored environmental reporting practices among publicly listed companies in Malaysia and Australia and investigated the potential influencing factors of environmental disclosures made in corporate annual reports. This study seeks to investigate environmental reporting practices made via other reporting medium, other than the annual report of publicly listed companies. Such an investigation facilitates understandings about a company's strategy and initiative in reporting environmental information towards fulfilling the needs and demands for environmental information by various stakeholders' groups as well as gaining their support for the company's 
activities. Investigation of companies' inter-country reporting practices, i.e. Malaysia and Australia will further offer knowledge about the similarities and/or differences in environmental reporting practice in developing/developed and Eastern/Western economic, social and political settings.

\section{Underpinning Theoretical Orientation of Environmental Reporting}

Corporations have social contracts with the society in which they operate, hence raising the pressure for the discharge of accountability. Companies perceived as environmentally negligent have been accused of mismanagement and recklessness (Chan \& Welford 2005), thus disclosing environmental information is important to demonstrate accountability. Accountability represents the right to receive information and the duty to supply information (Gray et al. 1988).

The development of an accountability system in a company encompasses two main purposes: (1) to establish closer social relationships and (2) to increase an organisation's transparency (Gray 1992). Gray et al. (1996) describe accountability from the economic perspective, based on the corporation-shareholders relationship. This relationship requires that a company produce financial information that informs the extent of compliance with standards, laws, and other regulation of a quasi-legal nature (Gray et al. 1988).

According to Gray (1992), the concept of accountability cultivated in accounting systems helps to inform: (1) corporate interest groups about the extent of corporate environmental activities; and (2) society as a whole on how a corporation manages its resources as well as the process of maintaining and sustaining the environment. Lehman (1995) articulates that environmental reporting "establishes and articulates an accountability relationship between corporations and others" (p. 408) including an association between people and nature. These arguments imply that environmental reporting aids the discharge of a corporation's accountability and at the same time increases environmental transparency in environmental matters.

Based on the stakeholder theory, a company acknowledges the multiple settings of stakeholder groups. In addition to the accountability aspect, stakeholder theory has a second dimension, i.e. stakeholder management (see Ullman 1985). Stakeholders of companies are gradually becoming aware of corporate operations (Sobhani et al. 2009). Roberts (1992) empirically examines social reporting activity using Ullman's (1985) stakeholder framework in a study on the disclosure practices of 130 major corporations. The study discovers a significant correlation between stakeholder power, strategic posture, economic performance and the levels of social and environmental disclosures. The study findings indicate that the more critical the stakeholders' control is, the more likely companies will satisfy the demands of stakeholders (also see Ullman 1985). Hence, in this case, corporate social responsibility reporting is viewed as a strategic management tool.

Previous studies also utilised stakeholder theory to explore the role that stakeholder participants play in influencing corporate decisions (e.g. McGuire et al. 1988). In particular, Freeman (1984) provides insights into the dynamics of stakeholder influences on corporate decisions. Identification of the primary needs of each group of stakeholders (internal and external) is crucial in deciding the types of environmental information to be produced. In relation to social and environmental disclosure practice in corporate annual reports, it is argued that it is useful for corporations to effectively manage the needs of multiple stakeholders (Neu et al. 1998).

Above all, theories of accountability and stakeholder provide the foundations for this study to investigate corporate environmental reporting practices amongst companies in Malaysia and Australia.

\section{Research Studies on Corporate Environmental Reporting Practices}

Numerous research studies have been conducted to explore corporate environmental reporting practices using both the accountability and stakeholder theories. Market-based studies relating to corporate environmental reporting suggest that financial-related information is relevant and important to financial stakeholders (e.g. Li et al. 1997; Cormier \& Magnan 1999). In comparison, environmental information, other than financially related information, is found to be useful to stakeholder groups including government authorities, employees, NGOs, and the general public (e.g. Deegan \& Rankin 1996; Brown \& Deegan 1998; Bewley \& Li 2000). The existence of 
multiple stakeholder groups instigates the need to adopt different corporate strategies including those for the purposes of company survival, damage control, competitive advantage, and public policy effects. Voluntary disclosure practice is a socially responsible activity and is often used as a corporate strategy in managing stakeholders and portraying the image of good corporate citizenship (e.g. Gelb \& Strawser 2001). By being part of the stakeholder management strategy, corporations deem fulfilling stakeholders' information needs as essential (Buysse \& Verbeke 2003).

Among various groups of corporate stakeholders, financial investors have been found to have preferences for companies with 'good' social and environmental performance. According to Chan and Welford (2005), investors perceive sound environmental management as an essential part of corporate governance. However, they found that Hong Kong listed companies have failed to provide sufficient information for investors. Hummels and Timmer (2004) analyse social, ethical, and environmental disclosures of three multinational corporations and suggest that a company should distinguish the disclosures according to the type of investor-audience, and more financially-oriented information should be disclosed.

Under a broader management perspective that pertains to corporate-stakeholder relationships, Cormier et al. (2004) who investigate management's perceptions of environmental reporting, indicate that environmental disclosures function as a mechanism of corporate accountability. Gray et al. (1997) continue to promote the values of accountability as the driver for social and environmental accounting and recommend the use of a poly-vocal citizenship approach, known as 'stakeholder dialogue', in obtaining closer relationships with stakeholders.

The wide stakeholder groups of environmental disclosures and the emerging issues of globalisation and internalisation place great pressure on corporate environmental reporting practice in recent years. In particular, these issues create demands for discourse of environmental information via advancement in communicative technology (see Gallhofer et al. 2006). Business corporations began to expand their reporting strategies by using 'other' means of reporting i.e. the World Wide Web. The progression from hardcopy to Internet reporting implies that companies seek to reach a more diverse audience; hence, a strategy to develop broader corporate-stakeholders relationships. However, it is argued that this new reporting strategy is doubtful in securing better accountability (Abdul Hamid 2005; Adams \& Frost 2006a, b). Adams and Frost (2006a) explore Internet usage as a communication tool for social and environmental performance among selected Australian, German, and British companies. Through questionnaire and interview surveys, the study finds that environmental disclosures are rather limited. Such a finding suggests that companies are under-utilising new technologies for environmental reporting.

Generally, this strand of literature deems accounting and reporting as a system that is capable of functioning in a complex world consisting of societies with different beliefs, values, and understandings. The issue about the complex world setting is illustrated by Neu (2006), which posits accounting as being closely connected to the locality of the public space. Neu raises arguments about the different degree of 'network' relationships which consist of: (1) participation and interactions within the organisation itself, and (2) external interaction networks between the organisation and other participants. The literature provides an idea that prompts this study to explore whether companies in Malaysia and Australia effectively utilise and expand their technology for environmental reporting to a wider group of information users, hence using various means of corporate environmental communication.

\section{RESEARCH METHODOLOGY}

This study applies content analysis technique in exploring environmental reporting practices of companies in Malaysia and Australia. From a statistical point of view, content analysis according to Neuman (2003) represents:

a technique for gathering and analyzing the context of text...content covers words, meanings, pictures, symbols, ideas, themes, or any message that can be communicated while text means anything written, visual, or spoken that serves as communication medium... (p. 310).

The utilisation of content analysis in this study is based on two key reasons: (1) an approach that gains acceptance from researchers due to the fact that the data collected is objective, systematic and reliable; and (2) one 
of the most reliable ways of obtaining meaningful measures of social and environmental activities (e.g. Hackson \& Milne 1996; Cormier et al. 2004; Zeng et al. 2010).

Content analysis was conducted on other corporate reports besides annual reports. Corporate websites provided the initial source of reference. Other reporting forms are referenced through the information provided on the Web, which led to further investigation of these reporting forms: stand-alone environmental reports, social and sustainability reports, corporate websites, and corporate newsletters.

A non-probability sampling method is used by selecting the top 50 Malaysian companies listed under Bursa Malaysia (BM) (formerly known as the Kuala Lumpur Stock Exchange) and the top 50 Australian companies listed on the Australian Stock Exchange (ASX) ${ }^{1}$. The sample is based on the criterion of a 'large' company, based on the previous observation that larger companies disclose larger volumes of environmental information (e.g. Cowen et al. 1987; Gray et al. 1995; Deegan \& Gordon 1996; Bewley \& Li 2000; Cormier \& Magnan 2003). Imam (2000) finds that only large companies reported social and environmental information in their annual reports. These companies undertake a greater variety of activities, have a greater impact on civil society, and also tend to have larger numbers of stakeholders who demand social and environmental information. Thus, they are more likely to respond to environmental agenda in comparison with small or medium-sized companies.

A modified disclosure index of Wiseman's (1982) coding scheme is used as the interrogation instrument to facilitate analysis of the content of disclosures. An index was deemed relevant to study the environmental practices of selected companies in these two countries based on the fact that it allows for an objective measurement of disclosures, as well as the development of a systematic numerical basis for a further examination of disclosures (also Deegan \& Gordon 1996; Burritt \& Welch 1997; Walden \& Schwartz 1997; Bewley \& Li 2000; Hughes et al. 2001).

An environmental disclosure, as investigated in this study, includes any written passage about company's environmental issue and activity. This study incorporates four data rating scales, which include:

$$
\begin{array}{lll}
- & \text { General }(\mathrm{GEN}) & \text { = general information about environmental matters; } \\
\text { - } & \text { Qualitative (QUA) } & \text { = qualitative information about environmental matters; } \\
\text { - } & \text { Combination (COM) } & \text { = quantitative information about environmental matters; } \\
& \text { a combination of qualitative and quantitative information. }
\end{array}
$$

A mean score for each item of environmental information is used to measure the extensiveness of disclosures. Scores, which range from 1 to 4 , are assigned according to the presence and the degree of specificity for each group of environmental data (e.g. ' 1 ' is for GEN, '2' is for QUA, ' 3 ' is for QUAN, and ' 4 ' is for COM). A zero score is assigned when no environmental item is present.

Regression analysis, which is performed in this study, is based on this model:

$$
\text { EnvScore }=\beta_{0}+\beta_{1}(\text { SECTOR })+\beta_{2}(\mathrm{ISO})+\beta_{3}(\mathrm{EBIT})+\beta_{4}(\mathrm{EPS})+\beta_{5}(\mathrm{ROA})+\beta_{6}(\mathrm{ROE})+\beta_{7}(\text { Netmargin })+\varepsilon
$$

where:

$$
\begin{aligned}
& \beta_{0} \quad=\text { intercept terms } \\
& \beta_{1}, \beta_{2}, \ldots \beta_{7}=\text { coefficient of slope parameters; change in environmental disclosures associated with unit change in } \\
& \text { respective variables } \\
& \text { EnvScore } \quad=\text { total environmental scores of all environmental information } \\
& \text { SECTOR = dummy variables for type of industry sector; }(0=\text { non-environmental sensitive and } 1= \\
& \text { environmental sensitive) } \\
& \text { ISO }=\text { dummy variables for ISO } 14001 \text { certification; }(0=\text { non-ISO company and } 1=\text { ISO company })
\end{aligned}
$$

\footnotetext{
${ }^{1}$ Such a sample size is deemed comparable to the previous studies of Guthrie and Parker (1990), Freedman and Wesley (1990), and Hackston and Milne (1997). Furthermore, the sample size exceeds that of some earlier studies for example, Wiseman (1982) -20 largest companies; and Halme and Huse (1997) -40 largest companies.
} 


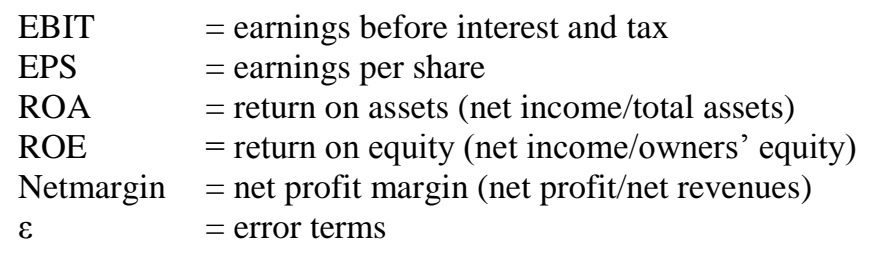

\section{RESULTS}

\section{Descriptive Statistics}

Twenty-eight of 50 Malaysian companies $(56 \%)$ were found to have disclosed some environmental information in their 'other' reports, and of these companies, only seven $(25 \%)$ use more than one medium for environmental reporting. In contrast, 35 of the 50 Australian companies $(70 \%)$ made environmental disclosures, with $18(51.4 \%)$ of companies reporting in more than one medium. A descriptive comparison of the disclosure of environmental information in 'other' reports was five times greater in Australia (517 disclosures) than that in Malaysia (107 disclosures). In general, this finding indicates a consistent result of earlier examination on environmental disclosures made in corporate annual reports (see Yusoff \& Lehman 2008).

Table 1 shows that among 'other' reports, the corporate website is the most popular means of communication for environmental reporting in both countries (72.2\% in Malaysia and $60.7 \%$ in Australia). Generally, the use of varies means of communication among companies in both countries represents the characteristic of new technologies and more advanced reporting (Gallhofer et al. 2006).

Table 1: Other Means of Communication for Environmental Reporting

\begin{tabular}{lcccc}
\hline \multirow{2}{*}{ Report Type } & \multicolumn{2}{c}{ Malaysia } & \multicolumn{2}{c}{ Australia } \\
\cline { 2 - 5 } & Number & \% & Number & \% \\
\hline Environmental report & 1 & 2.8 & 5 & 8.9 \\
Other stand-alone report & 3 & 8.3 & 13 & 23.2 \\
Corporate websites & 26 & 72.2 & 34 & 60.7 \\
Newsletter & 6 & 16.7 & 4 & 7.1 \\
\hline Total & $\mathbf{3 6}$ & $\mathbf{1 0 0 . 0}$ & $\mathbf{5 6}$ & $\mathbf{1 0 0 . 0}$ \\
\hline
\end{tabular}

Note: Some companies reported in multiple means of communication

Despite the use of various means of communication for environmental reporting, the extensiveness of environmental disclosures in 'other' reports is similar trend to those in corporate annual reports. Generally, environmental disclosures in 'other' reports are general and qualitative in nature, and much of the information is also available in the annual reports (see also Gibson \& O'Donovan 2000).

Table 2 shows the comparative summary of results found in this study and in Yusoff and Lehman (2008). Comparatively, environmental disclosures in 'other' reports are generally more extensive than those made in annual reports, as found in Yusoff and Lehman (2008). Of the six (6) themes studied, all items in the last four (4) themes showed higher mean average (both Malaysia and Australia) when compared to disclosures made in annual report; as found in Yusoff and Lehman (2008). In particular, disclosures pertaining to environmental cost accounting (financial factor), environmental data (pollution abatement) and all the six (6) environmental items under the category environmental initiatives have higher mean scores than those reported in annual report ranging from qualitative, quantitative, and a combination of qualitative and quantitative information. This form of environmental reporting indicates that companies in both Malaysia and Australia strategically disclose environmental information. Reports other than annual reports are increasingly used as a platform for companies to communicate about their environmental activities and initiatives to wide group of stakeholders. The variety in the modes of environmental reporting, from hardcopy to Internet reporting, implies that companies are making additional efforts to reach and fulfil the needs and demands of a more diverse audience of environmental information. Such efforts could support company's initiative towards better corporate-stakeholder relationships (see Arnott \& Bridgewater 2002; Haddock 2005). 
Table 2: Meta-Analysis: Mean Scores for Environmental Disclosures in Various Reports in Malaysia and Australia

\begin{tabular}{|c|c|c|c|c|}
\hline \multirow{3}{*}{ Environmental Item } & \multicolumn{2}{|c|}{$\begin{array}{c}\text { Current Study } \\
\text { Disclosures in 'Other' Reports }\end{array}$} & \multicolumn{2}{|c|}{$\begin{array}{c}\text { Yusoff \& Lehman (2008) } \\
\text { Disclosures in Annual Report }\end{array}$} \\
\hline & Malaysia & Australia & Malaysia & Australia \\
\hline & \multicolumn{4}{|c|}{ Mean Score } \\
\hline \multicolumn{5}{|l|}{ Financial Factors } \\
\hline Past and current environmental expenditures & 3.00 & 3.63 & Nil & 3.25 \\
\hline Future estimates of environmental expenditures & Nil & Nil & Nil & 3.25 \\
\hline Financing for environmental equipment & Nil & 3.00 & Nil & 2.67 \\
\hline Environmental cost accounting & 3.00 & 4.00 & Nil & 2.00 \\
\hline Average Mean Score & 3.00 & 3.54 & Nil & 2.85 \\
\hline \multicolumn{5}{|l|}{ Environmental Litigation } \\
\hline Past and present litigation & Nil & 3.08 & Nil & 3.75 \\
\hline Potential litigation & Nil & Nil & Nil & Nil \\
\hline Average Mean Score & Nil & 3.08 & Nil & 3.75 \\
\hline \multicolumn{5}{|l|}{ Pollution Abatement } \\
\hline Environmental data & 4.00 & 3.88 & 2.17 & 2.44 \\
\hline Control, installations, facilities or processes described & 1.83 & 2.26 & 1.82 & 2.21 \\
\hline Land rehabilitation and remediation & Nil & 2.54 & 2.00 & 2.00 \\
\hline Average Mean Score & 2.92 & 2.89 & 1.99 & 2.22 \\
\hline \multicolumn{5}{|l|}{ Environmental Preservation } \\
\hline Conservation of natural resources & 1.78 & 2.30 & 2.00 & 1.81 \\
\hline Departments or offices for pollution control & 2.00 & 1.73 & 1.63 & 1.76 \\
\hline Average Mean Score & 1.89 & 2.02 & 1.82 & 1.79 \\
\hline \multicolumn{5}{|l|}{ Other Environmentally Related Information } \\
\hline Discussion of regulations and requirements & 1.38 & 1.88 & 1.46 & 1.69 \\
\hline Environmental policies or company concern & 1.61 & 1.91 & 1.68 & 1.53 \\
\hline Environmental goals and targets & 1.57 & 1.95 & 1.40 & 1.67 \\
\hline Awards for environmental protection & 1.80 & 1.90 & 1.44 & 1.63 \\
\hline Environmental audit & 2.00 & 1.71 & 1.33 & 1.36 \\
\hline Environmental Management System & 1.80 & 2.16 & 1.21 & 1.50 \\
\hline Environmental end products/services & 1.50 & 1.96 & 1.60 & 1.73 \\
\hline Average Mean Score & 1.67 & 1.92 & 1.45 & 1.59 \\
\hline \multicolumn{5}{|l|}{ Environmental Initiatives } \\
\hline Sustainable development reporting & 2.50 & 2.40 & 1.67 & 1.79 \\
\hline Environmental memberships/relationships & 2.00 & 1.97 & 1.80 & 1.64 \\
\hline Environmental stakeholder engagement & 2.00 & 1.70 & 1.00 & 1.60 \\
\hline Environmental activities & 2.18 & 2.48 & 2.00 & 2.35 \\
\hline Environmental research and development & 2.67 & 2.00 & 1.75 & 2.00 \\
\hline Environmental awareness and education programmes & 2.33 & 1.95 & 1.50 & 1.33 \\
\hline Average Mean Score & 2.28 & 2.08 & 1.62 & 1.79 \\
\hline No. of Companies (\%) & $28(56 \%)$ & $35(70 \%)$ & $37(74 \%)$ & $50(100 \%)$ \\
\hline
\end{tabular}

Nevertheless, when focus on the extensiveness of environmental disclosures is made, it can be argued that companies in Malaysia and Australia had simplistically used 'other' reports in communicating their environmental information to corporate stakeholders. Such an assertion is supported by the rather low extent of environmental disclosures made both in 'other' reports and annual reports (refer to the mean scores of environmental items in Table 2).

\section{Regression Analysis}

Table 3 below shows that the regression analysis conducted on the relationship between the influencing factors for environmental disclosures among selected Malaysian companies and the actual disclosures made by them had resulted in an adjusted $\mathrm{R}^{2}$ value of .237 . This finding also indicates that only $23.7 \%$ of the variation in environmental disclosures is due to the ISO 14001 certification factor. This result suggests that ISO 14001 
certification is the sole significant factor influencing environmental disclosure practice in 'other' reports among Malaysian companies.

Table 3: Regression of Malaysian Environmental Reporting in 'Other' Reports

\begin{tabular}{|c|c|c|c|c|c|c|}
\hline & D.f. & Sum of Squares & & Mean Square & t-ratio & p-value \\
\hline Regression & 1 & 1753.515 & & 1753.515 & 16.181 & $<.001$ \\
\hline Residual & 48 & 5201.605 & & 108.367 & & \\
\hline Variable & & $\mathbf{B}$ & Beta & & & p-value \\
\hline Constant & & 5.730 & & & & \\
\hline ISO & & 13.501 & .502 & & & $<.001$ \\
\hline
\end{tabular}

Multiple $\mathrm{R}=.502, \mathrm{R}_{2}=.252$, Adjusted $\mathrm{R}^{2}=.237$, Std. error $=10.410$

A similar factor was found to be significant when compared to the regression analysis for environmental reporting in annual reports made in Yusoff and Lehman (2008). Nevertheless, they found that only $11 \%$ (adjusted $\mathrm{R}^{2}=.110$ ) of the variations in environmental disclosures made in annual reports were due to the ISO 14001 certification factor. Both findings relating to environmental disclosures in annual report and 'other' reports indicate that ISO 14001 certification plays a significant role in influencing companies in Malaysia to disclose environmental information in multiple forms of means of communication.

Table 4 presents the results of the regression analysis performed on disclosures by Australian companies in 'other' reports. The regression model is found to be significant (adjusted $\mathrm{R}^{2}=.442$ ), and ISO certification and SECTOR are found to be significantly correlated to environmental disclosures. This interaction value (adjusted $\mathrm{R}^{2}$ ) shows that 44.2 of the variation in Australian disclosures are related to these two factors. Also, when compared to the findings by Yusoff and Lehman (2008), these two factors were also found to be significant to environmental disclosures in annual reports, along with a negative relationship of EPS; with adjusted $\mathrm{R}^{2}$ of .428 .

Table 4: Regression of Australian Environmental Disclosures in 'Other' Reports

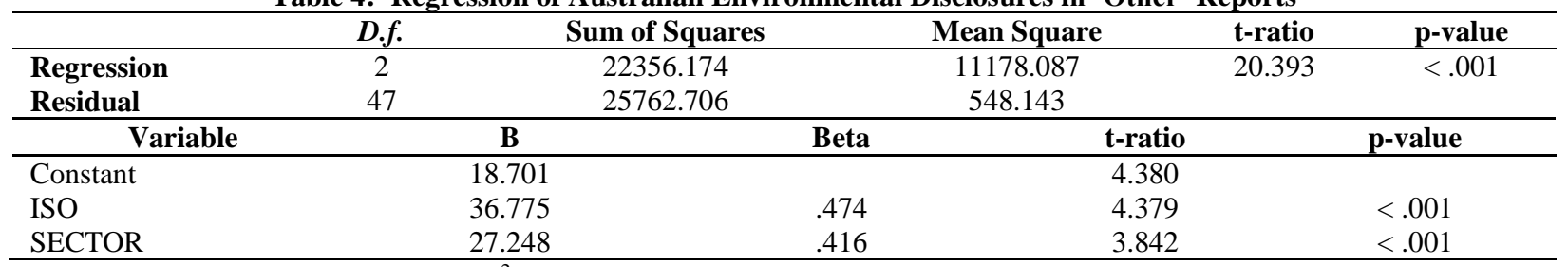

Multiple $\mathrm{R}=.682, \mathrm{R}_{2}=.465$, Adjusted $\mathrm{R}^{2}=.442$, Std. error $=23.412$

Comparatively, environmental disclosure practice in Australia is influenced by the accreditation of ISO standard and the type of industry while the disclosure practice in Malaysia is only influenced by the first factor. Here, it can be argued that the low adjusted $\mathrm{R}^{2}$ scores ('other' report: .237 and annual report: .110) obtained from the Malaysian results signal that there are other factors that influence environmental disclosure practice in the country. Such a finding supports the literature that environmental reporting in a developing country is yet to develop (e.g. Nik Ahmad \& Sulaiman 2002; ACCA 2004; Yusoff et al. 2005). Despite such reporting conditions, the growing corporate efforts in Malaysia as well as Australia to use varied means of environmental communication are acknowledged.

\section{CONCLUSION}

The corporate environmental reporting in both Malaysia and Australia studied in this paper has shown the reporting practice is predominantly general and qualitative in nature. Comparatively, results pertaining to similar quality of environmental disclosures in corporate annual reports and 'other' reports in both countries, as well as the type of influencing factors of environmental disclosures, imply that companies in these countries are yet to achieve good corporate reporting accountability. Hence, there is an urgent need to understand the motivation for greater business engagement into environmental reporting.

The minimal progress between environmental reporting in 'other' reports and annual report poses a key question that relates to whether companies in these two different countries are only jumping onto the bandwagon of 
current environmental reporting practice. Is this an effective way of companies leveraging technology to portray their corporate accountability towards caring for the environment? If so, such an environmental reporting trend worries all because it could promote an act of manipulating corporate image.

Importantly and arguably, we want 'real' (and ethical) business engagement into environmental accountability and not one that favours only market-driven motives and incentives. One reason may be these companies seldom integrated environmental issues and management into their corporate goals or business strategies. Nevertheless, a growing effort in simplicity is not a way to move forward for environmental reporting.

This study has some limitations. Firstly, the data is not recent and therefore the designed content analysis for this study might not cover recent items that might be relevant to the context of the study. The small sample size limits the generalisation of this study. Future studies may be undertaken to overcome these limitations. In terms of reporting channels, this study finds that other reports are more favourable than annual reports in disclosing environmental information. Since annual reports have been designed for investors' attention, the underlying reasons that hinder these companies from reporting their environmental accountability in annual reports might be worth exploring.

\section{ACKNOWLEDGEMENT}

The authors are grateful to the Ministry of Higher Education of Malaysia and Universiti Teknologi Mara, Malaysia for awarding the Exploratory Research Grant Scheme (ERGS).

\section{AUTHOR INFORMATION}

Haslinda Yusoff is an Associate Professor with Universiti Teknologi MARA, Malaysia. She has research interests in topics pertaining to environmental reporting, corporate social responsibility, and sustainability management and practice. She has a number of publications in a number of internationally refereed journals including Business Strategy and the Environment, Journal of Cleaner Production and Asian Review of Accounting. E-mail: hasli229@salam.uitm.edu.my

Radiah Othman is a Senior Lecturer with Massey University, New Zealand. She has research interests in social accountability depicted through disclosures and reporting, and public sector auditing. She published in various internationally refereed journals such as Corporate Social Responsibility and Environmental Management, Journal of Business Ethics, International Journal of Disclosure and Governance. E-mail: r.othman@massey.ac.nz (Corresponding author)

Normahiran Yatim is a Lecturer with Universiti Teknologi MARA, Malaysia. She has research interests in accounting information system, public sector accounting and environmental reporting and management practices. She has published in journals such as Malaysian Accounting Review and Asian Review of Accounting. E-mail: normah900@salam.uitm.edu.my

\section{REFERENCES}

1. Abdul Hamid, F. Z. 2005. Malaysian Companies' Use of the Internet for Investor Relations. Corporate Governance. 5(1) 5-14.

2. ACCA. 2004. The State of Corporate Environmental and Social Reporting in Malaysia 2004. Malaysia: The Association of Chartered Certified Accountants, ACCA Malaysia Sdn. Bhd.

3. Adams, C. A., Frost, G. R. 2006a. The Internet and Change in Corporate Stakeholder Engagement and Communication Strategies on Social and Environmental Performance. Journal of Accounting \& Organizational Change. 2(3) 281-303.

4. Adams, C. A., Frost, G. R. 2006b. Accessibility and Functionality of the Corporate Web Site: Implications for Sustainability Reporting. Business Strategy and the Environment. 15(4) 275-287.

5. Arnott, D. C., Bridgewater, S. 2002. Internet, Interaction and Implications for Marketing. Marketing Intelligence \& Planning. 20(2) 86-95. 
6. Bewley, K., Li, Y. 2000. Disclosure of Environmental Information by Canadian Manufacturing Companies: A Voluntary Disclosure Perspective. Advances in Environmental Accounting and Management. 1, 201-226.

7. Brown, N., Deegan, C. M. 1998. The Public Disclosure of Environmental Performance Information - A Dual Test of Media Agenda Setting Theory and Legitimacy Theory. Accounting and Business Research. 29(1) 21-41.

8. Burritt, R. L., Welch, S. 1997. Australian Commonwealth Entities: An Analysis of Their Environmental Disclosures. Abacus. 33(1) 69-87.

9. Buysse, K., Verbeke, A. 2003. Proactive Environmental Strategies: A Stakeholder Management Perspective. Strategic Management Journal. 24, 453-470.

10. Chan, J.C. Welford, R. 2005. Assessing Corporate Environmental Risk in China: An Evaluation of Reporting Activities of Hong Kong Listed Enterprises. Corporate Social Responsibility and Environmental Management. 12, 88-104.

11. Cormier, D., Magnan, M. 1999. Corporate Environmental Disclosure Strategies: Determinants, Costs and Benefits. Journal of Accounting, Auditing \& Finance, 14(4), 429-451.

12. Cormier, D., Magnan, M. 2003. Environmental Reporting Management: A Continental European Perspective. Journal of Accounting and Public Policy. 22(1), 43-62.

13. Cormier, D., Gordon, I. M., Magnan, M. 2004. Corporate Environmental Disclosure: Contrasting Management's Perceptions with Reality. Journal of Business Ethics. 49(2), 143-165.

14. Cowen, S. S., Ferreri, L. B., Parker, L. D. 1987. The Impact of Corporate Characteristics on Social Responsibility Disclosure: A Typology and Frequency-based Analysis. Accounting, Organizations and Society. 12(2) 111-122.

15. Deegan, C., Gordon, B. 1996. A Study of the Environmental Disclosure Practices of Australian Corporations. Accounting and Business Research. 26(3) 187-199.

16. Deegan, C., Rankin, M. 1996. Do Australian Companies Report Environmental News Objectively? An Analysis of Environmental Disclosures by Firms Prosecuted Successfully by the EPA. Accounting, Auditing \& Accountability Journal. 9(2) 50-67.

17. Freedman, M., Wesley, C. 1990. The Association between Environmental Performance and Environmental Disclosure in Annual Reports and 10Ks. Advances in Public Interest Accounting. 3, 183-193.

18. Freeman, R.E. (1984), Strategic Management: A Stakeholder Approach, Pittman, Marshfield, MA.

19. Gallhofer, S., Haslam, J., Monk, E., Roberts, C. 2006. The Emancipatory Potential of Online Reporting: The Case of Counter Accounting. Accounting, Auditing \& Accountability Journal 19(5), 681-718.

20. Gelb, D. S., Strawser, J. A. 2001. Corporate Social Responsibility and Financial Disclosures: An Alternative Explanation for Increased Disclosure. Journal of Business Ethics. 33(1), 1-13.

21. Gibson, K., O'Donovan, G. 2000. Environmental Disclosures in Australia: A Longitudinal Study. Paper presented at the 6th Interdisciplinary Environmental Association Conference, 21-24 July, Montreal.

22. Gray, R. 1992. Accounting and Environmentalism: An Exploration of the Challenge of Gently Accounting for Accountability, Transparency and Sustainability. Accounting, Auditing \& Accountability Journal. 17(5) 399-425.

23. Gray, R., Dey, C., Owen, D., Evans, R., Zadek, S. 1997. Struggling with the Praxis of Social Accounting: Stakeholders, Accountability, Audits and Procedures. Accounting, Auditing \& Accountability Journal. 10(3) 325-364.

24. Gray, R., Kouhy, R., Lavers, S. 1995. Corporate Social and Environmental Reporting: A Review of the Literature and a Longitudinal Study of UK Disclosure. Accounting, Auditing \& Accountability Journal. $8(2)$ 47-77.

25. Gray, R., Owen, D., Adams, C. 1996. Accounting \& Accountability: Changes and Challenges in Corporate Social and Environmental Reporting. London New York: Prentice Hall.

26. Gray, R., Owen, D., Maunders, K. 1988. Corporate Social Reporting: Emerging Trends in Accountability and the Social Contract. Accounting, Auditing \& Accountability Journal. 1(1) 6-20.

27. Gray, R., Owen, D., Maunders, K. 1991. Accountability, Corporate Social Reporting and the External Social Audits. Advances in Public Interest Accounting. 4, 1-21.

28. Guthrie, J. E., Parker, L. D. 1990. Corporate Social Disclosure Practice: A Comparative International Analysis. Advances in Public Interest Accounting. 3, 159-175. 
29. Hackston, D., Milne, M. J. 1996. Some Determinants of Social and Environmental Disclosures in New Zealand Companies. Accounting, Auditing \& Accountability Journal. 9(1) 77-108.

30. Haddock, J. 2005. Consumer Influence on Internet-based Corporate Communication of Environmental Activities: The UK Food Sector. British Food Journal. 107(10) 792-805.

31. Hughes, S. B., Anderson, A., Goldenc, S. 2001. Corporate Environmental Disclosures: Are They Useful in Determining Environmental Performance? Journal of Accounting and Public Policy. 20(3) 217-240.

32. Hummels, H., Timmer, D. 2004. Investors in Need of Social, Ethical, and Environmental Information. Journal of Business Ethics. 52 73-84.

33. Imam, S. 2000. Corporate Social Reporting in Bangladesh. Managerial Auditing Journal. 15(3) 133-141.

34. Lehman, G. 1995. A Legitimate Concern for Environmental Accounting. Critical Perspectives on Accounting. 6(5) 393-412.

35. Li, Y., Richardson, G. D., Thornton, D. B. 1997. Corporate Disclosure of Environmental Liability Information: Theory and Evidence. Contemporary Accounting Research. 14(3) 435-474.

36. McGuire, J. B., Sundgren, A., Schneeweis, T. 1988. Corporate Social Responsibility and Firm Performance. Academy of Management Journal. 31(4) 854-872.

37. Neu, D. 2006. Accounting for Public Space. Accounting, Organizations and Society. 31(4-5) 391-414.

38. Neu, D., Warsame, H., Pedwell, K. 1998. Managing Public Impressions: Environmental Disclosures in Annual Reports. Accounting, Organizations and Society. 23(3) 265-282.

39. Neuman, W. L. 2003. Social Research Methods: Qualitative and Quantitative Approaches (5th ed.), Boston, Allyn and Bacon.

40. Nik Ahmad, N. N., Sulaiman, M. 2002. Environmental Disclosures in Malaysian Annual Reports: A Study of the Construction and Industrial Products Sectors. Paper presented at the European Accounting Association 25th Annual Congress, Copenhagen Business School, Denmark.

41. Patten, D. M. 2002. The Relation between Environmental Performance and Environmental Disclosure: A Research Note. Accounting, Organizations and Society. 27(8) 763-773.

42. Roberts, C. B. 1992. Environmental Disclosures in Corporate Annual Reports in Western Europe in Owen, D.L. (eds). London, Chapman and Hall.

43. Schaltegger, S., Burritt, R. 2000. Contemporary Environmental Accounting: Issues, Concept and Practice. Sheffield, Greenleaf.

44. Sobhani, F.A., Amran, A., Zainuddin, Y. 2009. Revisiting the Practices of Corporate Social and Environmental Disclosures in Bangladesh. Corporate Social Responsibility and Environmental Management, 16, 167-183.

45. Ullmann, A. A. 1985. Data in Search of a Theory: A Critical Examination of the Relationships among Social Performance, Social Disclosure and Economic Performance of the U.S. Firms. Academy of Management Review. 10(3), 540-557.

46. Walden, W. D., Schwartz, B. N. 1997. Environmental Disclosures and Public Policy Pressure. Journal of Accounting and Public Policy. 16(2) 125-154.

47. Wiseman, J. 1982. An Evaluation of Environmental Disclosures Made in Corporate Annual Reports. Accounting, Organizations and Society. 7(1) 53-63.

48. Yusoff, H., Lehman, G. 2008. International Differences on Corporate Environmental Accounting Developments: A Comparison between Malaysia and Australia, Accounting and Finance in Transition. 4, Greenwich University Press, 92-124.

49. Yusoff, H., Mohd Nasir, N., Yatim, N. 2005. Analysis on the Development of Environmental Reporting From 1999 - 2002. Malaysian Accounting Review. 4(1) 49-73.

50. Zeng, S.X., Xu, X.D., Dong, Z.Y., Tam, V.M.Y. 2010. Towards Corporate Environmental Information Disclosure: An Empirical Study in China. Journal of Cleaner Production.

doi:10.1016/j.jclepro.2010.04.005. 